\title{
Pengaruh Variasi Lapisan Pelat Sejajar pada Laju Produksi HHO dari Generator Oxyhydrogen Berbasis Sel Elektrolisis
}

\author{
Arifin Syaiful, Bachtera Indarto, ${ }^{*}$ Didiek Basuki Rahmat, dan Hasto Sunarno \\ Jurusan Fisika, Fakultas Matematika dan Ilmu Pengetahuan Alam, \\ Institut Teknologi Sepuluh Nopember (ITS), Kampus ITS Sukolilo, Surabaya 60111
}

Intisari

\begin{abstract}
Telah dilakukan pengukuran nilai resistansi fuel cell terhadap variasi lapisan pelat sejajar, hasilnya penggunaan logam SS316 menghasilkan resistansi lebih rendah bila dibandingkan dengan logam aluminium. Dari beberapa variasi lapisan pelat sejajar yang yang dicoba, diperoleh kenaikan arus listrik yang mengalir pada fuel cell. Laju produksi HHO semakin meningkat dengan bertambahnya arus listrik yang mengalir.
\end{abstract}

\section{Abstract}

Resistance measurement of the variation of the fuel cell layers parallel plates has been done, the result is the use of metal SS316 produce lower resistance when compared to aluminum metal. Of several variations of parallelplate layer is tested, obtained increase in the electrical current flowing in the fuel cell. HHO production rate increasing with increasing electric current flowing.

KATA KUNCI:

\section{PENDAHULUAN}

Bahan bakar fosil merupakan sumber utama untuk memenuhi kebutuhan energi, terutama dalam bidang transportasi. Sebagai sumber energi, bahan bakar fosil memiliki banyak kelemahan misalnya dapat menghasilkan gas $\mathrm{CO}_{2}$ yang menimbulkan efek kerusakan lapisan ozon sehingga terjadi pemanasan global. Bahan bakar fosil juga merupakan sumber pencemaran udara karena dapat mengemisikan gas seperti $\mathrm{CO}_{2}, \mathrm{NO}_{2}$. Selain itu bahan bakar fosil bersifat tidak dapat diperbaharui sehingga lama-kelamaan bahan bakar fosil akan habis [1].

Salah satu solusi yang dapat dipakai untuk mengatasi hal di atas adalah dengan menggunakan oxyhydrogen sebagai bahan bakar mengingat oxyhydrogen tidak menimbulkan polusi dan dapat diproduksi dengan mengelektrolisis air [2]. Oxyhydrogen sebagai bahan campuran dalam bahan bakar bensin juga terbukti mampu meningkatkan efisiensi mesin Otto [3]

Pada peristiwa elektrolisis, pemilihan bahan logam sebagai elektroda sangatlah penting mengingat hal tersebut dapat mempengaruhi reaksi kimia yang terjadi. Kuat arus listrik yang mengalir berperan penting dalam menghasilkan mol produk dari proses eletrolisis [4]. Kuat arus listrik bergantung pada resistansi media yang dilewati. Resistansi dari sel eletrolisis pelat sejajar bergantung antara lain pada luas permukaan pelat, jarak antar pelat, jenis logam pelat, dan jenis larutan yang dielektrolisis [5].

\footnotetext{
*E-MAIL: bachtera@physics.its.ac.id
}

Pada celah yang sempit, fluida akan bergerak dengan kecepatan yang berbanding lurus dengan lebar celah karena adanya gaya adhesi antara molekul fluida dan gaya kohesi antara fluida dengan dinding celah [6]. Pada proses elektrolisis dihasilkan gas yang dapat dipandang sebagai fluida yang akan bergerak pada celah antara pelat. Dengan jarak yang cukup dekat dimungkinkan gas akan terhambat untuk dapat keluar dari fuel cell, hal ini akan berpengaruh pada nilai resistansi larutan.

Pada proses elektrolisis air, gas yang dihasilkan yaitu $\mathrm{H}_{2}$ dan $\mathrm{O}_{2}$ dapat dianggap sebagai gas nyata yang persamaan keadaannya dapat dinyatakan dengan persamaan Van Der Walls.

$$
p-(b p+R T) \frac{n}{V}+a\left(\frac{n}{V}\right)^{2}-a b\left(\frac{n}{V}\right)^{3}=0
$$

dengan a dan $\mathrm{b}$ adalah konstanta, $\mathrm{p}=$ tekanan gas, $\mathrm{V}=$ volume gas, $\mathrm{T}=$ temperature absolute gas, $\mathrm{n}=$ jumlah mol dan $\mathrm{R}=$ konstanta gas umum.

Gas hidrogen dan oksigen yang dihasilkan dari reaksi kimia pada elektrolisis dapat membentuk gelembung pada elektroda. Mol hidrogen dan oksigen yang dihasilkan tersebut dapat dihitung dengan persamaan Faraday,

$$
n=\frac{i t}{F z}
$$

dengan, $\mathrm{F}=$ konstanta Faraday, $\mathrm{z}=$ bilangan valensi dari hidrogen atau oksigen. 


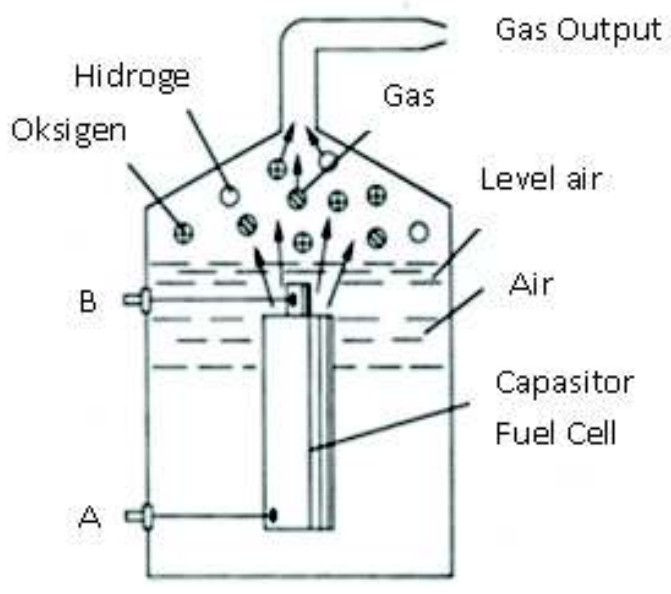

(a)

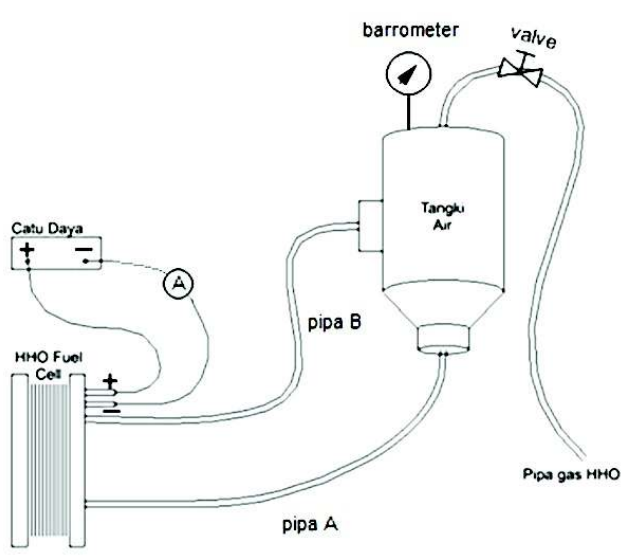

(b)

Gambar 1: (a). Skema Fuel Cell, (b) Rangkaian peralatan.

\section{METODOLOGI}

\section{A. Peralatan}

Pada penelitian ini digunakan peralatan yang dirangkai seperti pada Gambar 1, antara lain catu daya $12 \mathrm{~V}, 21 \mathrm{~A}$, Barometer (BMP180), HHO fuel cell, sensor arus, aquades. Catu daya mensuplai arus listrik ke HHO fuel cell, ampermeter akan mengukur kuat arus listrik secara langsung dan dikirim ke komputer. Pipa A berguna untuk mensuplai air ke fuel cell sedang pipa B untuk saluran keluarnya gas $\mathrm{HHO}$ yang diproduksi dalam fuel cell. Posisi tangki air diletakkan lebih tinggi untuk menjaga agar air didalam fuel cell tetap penuh. Barometer BMP180 digunakan untuk mengukur tekanan dan temperature gas dalam tangki air. Pengukuran dilakukan secara terus-menerus dan data langsung dikirim ke komputer.

\section{B. Pengambilan Data}

Mula-mula tangki air dikosongkan dan hanya disisakan air dalam fuel cell saja, lalu kran pada tangki ditutup. Setelah itu catu daya dinyalakan, ditunggu sampai tekanan udara dalam tangki mencapai 108 millibar, maka akan didapatkan data kuat arus, resistansi, temperatur dan tekanan. Pada penelitian ini pengukuran dilakukan dengan variasi lapisan pelat fuel cell antara lain jenis logam dari pelat, jarak antar lapisan pelat, jumlah lapisan pelat dan luas permukaan lapisan pelat.

\section{HASIL DAN PEMBAHASAN}

\section{A. Variasi jenis pelat}

Pada penelitian ini digunakan dua jenis pelat yaitu pelat Aluminium dan pelat SS316. Data hasil pengukuran dapat dilihat pada Gambar 2. Berdasarkan grafik dalam Gam-

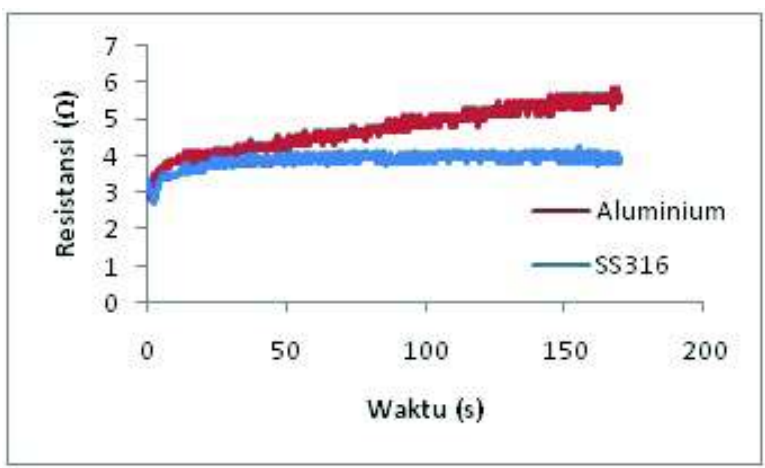

Gambar 2: Pengaruh waktu terhadap reistansi.

bar 2 terlihat bahwa resistansi listrik fuel cell dengan pelat aluminium mengalami peningkatan secara gradual sedangkan fuel cell dengan pelat SS316 resistansi listriknya relatif tetap. Peningkatan resistansi pada generator pelat aluminium disebabkan adanya butir-butir endapan yang menutupi pelat selama proses elektrolisis berlangsung.

\section{B. Variasi jarak antar pelat}

Pengujian pengaruh jarak antar pelat digunakan fuel cell dengan pelat SS316 dan didapatkan grafik seperti pada Gambar 3. Dalam Gambar 3 terlihat bahwa pada jarak antar pelat $\geq 2,10 \mathrm{~mm}$ nilai resistansi meningkat seiring dengan bertambahnya jarak antar pelat. Akan tetapi tidak demikian halnya untuk jarak pelat $\leq 2,10 \mathrm{~mm}$, nilai resistansi cenderung naik turun, hal ini disebabkan karena munculnya gelembung - gelembung udara yakni gas HHO pada proses elektrolisis air. Gelembung-gelembung ini dapat menghalangi terjadinya kontak antara permukaan pelat dengan molekul air sehingga menghambat terjadinya proses reaksi elektrolisis. Dari gambar juga terlihat semakin banyak jumlah pelat semakin kecil 


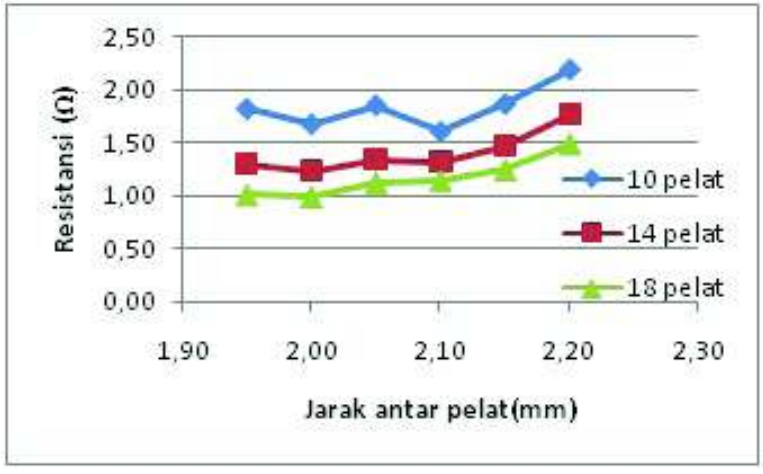

Gambar 3: Pengaruh jarak pelat terhadap resistansi.

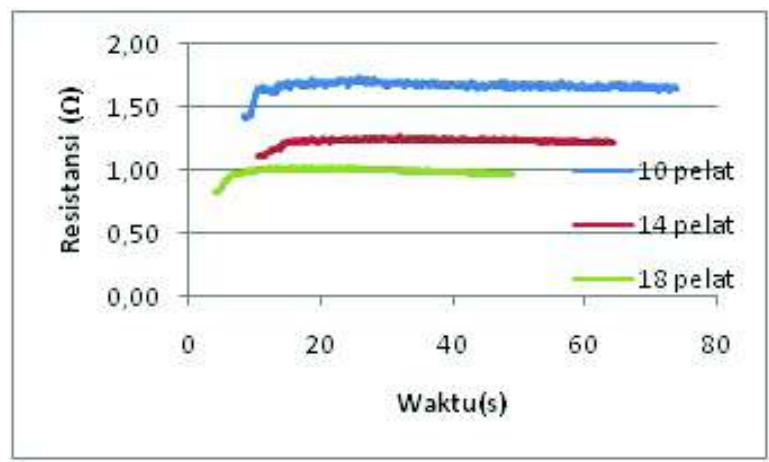

Gambar 4: Pengaruh waktu terhadap resistansi untuk jarak pelat 2 $\mathrm{mm}$.

nilai resistansi fuel cellnya.

Pada penelitian ini juga dilakukan pengukuran pengaruh waktu terhadap nilai resistansi untuk berbagai jumlah pelat pada jarak antar pelat $2 \mathrm{~mm}$ dengan hasil seperti pada Gambar 4. Gambar 4 menunjukkan bahwa pada saat pertama kali rangkaian alat dinyalakan gas $\mathrm{HHO}$ masih belum terbentuk sama sekali, resistansi masih rendah. Kemudian lama kelamaan akan meningkat akibat terbentuknya gas $\mathrm{HHO}$ yang menutupi permukaan pelat. Kemudian resistansi akan menuju nilai tetap yang artinya gelembung-gelembung gas $\mathrm{HHO}$ telah naik ke atas dan terbentuk secara teratur.

\section{Variasi luas permukaan pelat}

Luas permukaan pelat yang terendam dalam cairan sangat berpengaruh pada nilai resistansi fuel cell. Gambar 5 menunjukkan bahwa resistansi berbanding terbalik dengan luas permukaan pelat yang bersentuhan dengan air. Hal ini disebabkan dengan bertambah besar luas permukaan pelat maka jumlah muatan yang dapat berinteraksi dengan molekul molekul air akan semakin bertambah dengan demikian akan semakin banyak terjadi reaksi elektrolisis, akibatnya fuel cell akan menjadi lebih mudah menghantarkan listrik atau dengan kata lain resistansi menjadi lebih kecil. Grafik pada Gambar 5 berupa garis lurus yang sesuai dengan hubungan resistansi

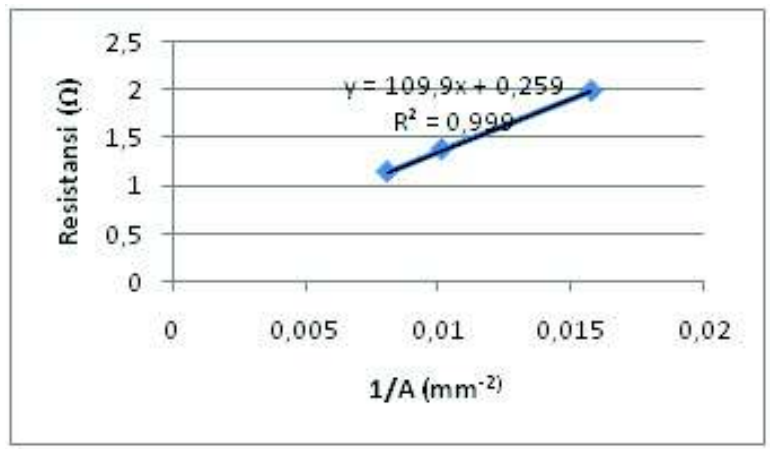

Gambar 5: Pengaruh luas permukaan pelat terhadap resistansi.

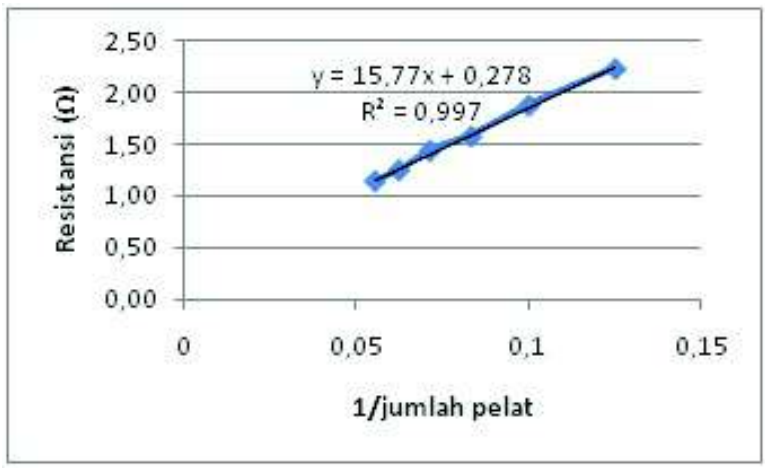

Gambar 6: Pengaruh jumlah pelat terhadap resistansi.

dengan luas penampang.

$$
R=\rho \frac{d}{n / 2}\left(\frac{1}{A}\right)
$$

dengan, $\mathrm{n} / 2=$ jumlah pasang elektroda $=18 / 2=9$

Dari grafik Gambar 5, diperoleh hubungan $\frac{\rho d}{n / 2}$, dan $\rho=$ $109,9 \times(9 / 0,2)=4710 \Omega \mathrm{cm}$.

\section{Variasi jumlah lapisan pelat}

Grafik pada Gambar 6, menunjukkan hubungan antar resistansi dengan seperjumlah lapisan pelat. Semakin banyak jumlah pelat semakin kecil nilai resistansi. Pada dasarnya jumlah berpengaruh pada luasan permukaan yang dapat menangkap muatan listrik. Hal ini serupa dengan pelat-pelat yang dirangkai paralel, semakin banyak jumlah pasang pelat yang dirangkai paralel, semakin kecil nilai resistansinya. Jadi dapat dikatakan nilai resistansi berbanding terbalik dengan jumlah pelat.

\section{E. Pengaruh kuat arus terhadap debit HHO}

Grafik pada Gambar 7, menunjukkan bahwa debit $\mathrm{HHO}$ yang diproduksi berbanding lurus dengan kuat arus yang mengalir pada fuel cell. Besarnya arus yang mengalir 


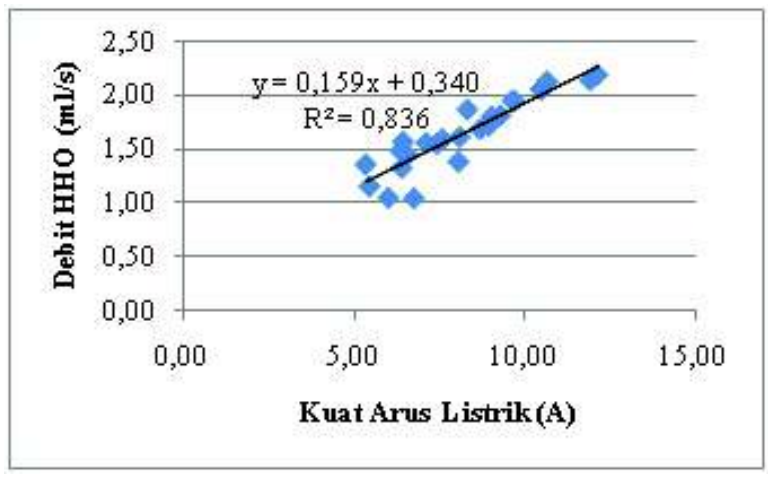

Gambar 7: Pengaruh kuat arus terhadap debit HHO.

mengindikasikan jumlah reaksi elektrolisis yang terjadi, semakin banyak reaksi yang terjadi semakin banyak pula jum- lah gas HHO yang dihasilkan. Dari hasil pengukuran yang telah dilakukan dengan variasi lapisan pelat diperoleh keadaan bahwa kuat arus listrik dipengaruhi oleh variasi-variasi lapisan pelat, dengan demikian dapat dikatakan variasi lapisan pelat dapat mempengaruhi debit HHO yang dihasilkan. Persoalannya apa betul hubungan arus dengan debit $\mathrm{HHO}$ berupa garis lurus, untuk itu dapat dianalisa sebagai berikut; Persamaan keadaan gas nyata

$$
p-(b p+R T) \frac{n}{V}+a\left(\frac{n}{V}\right)^{2}-a b\left(\frac{n}{V}\right)^{3}=0
$$

untuk hydrogen a $=0,244 \mathrm{bar}^{2} \mathrm{t}^{2} / \mathrm{mol}^{2}$ dan $\mathrm{b}=0,02661 \mathrm{lt} / \mathrm{mol}$ sedang untuk oksigen, $\mathrm{a}=1,36 \mathrm{bar} . \mathrm{lt}^{2} / \mathrm{mol}^{2}$ dan $\mathrm{b}=0,03803$ $\mathrm{lt} / \mathrm{mol}, \mathrm{p}=1008,08 \mathrm{mb}, \mathrm{T}=300 \mathrm{~K}, \mathrm{R}=0,08314 \mathrm{bar} . \mathrm{lt} / \mathrm{kmol}$. Dengan demikian diperoleh persamaan polynomial orde 3 dalam $\mathrm{n} / \mathrm{v}$.

Untuk gas Hidrogen

$$
-0,0065\left(\frac{n_{H_{2}}}{V_{H_{2}}}\right)^{3}+0,2453\left(\frac{n_{H_{2}}}{V_{H_{2}}}\right)^{2}-24,9842\left(\frac{n_{H_{2}}}{V_{H_{2}}}\right)+1,008=0
$$

Untuk gas Oksigen

$$
-0,0440\left(\frac{n_{O_{2}}}{V_{O_{2}}}\right)^{3}+1,382\left(\frac{n_{O_{2}}}{V_{O_{2}}}\right)^{2}-24,9896\left(\frac{n_{O_{2}}}{V_{O_{2}}}\right)+1,008=0
$$

Akar persamaan yang memenuhi adalah

$$
\begin{aligned}
& \frac{n_{H_{2}}}{V_{H_{2}}}=0,04036 \\
& \frac{n_{O_{2}}}{V_{O_{2}}}=0,04043
\end{aligned}
$$

Sehingga volume HHO nya adalah

$$
\begin{aligned}
V_{H H O} & =V_{H_{2}}+V_{O_{2}} \\
V_{H H O} & =\frac{n_{H_{2}}}{0,04036}+\frac{n_{O_{2}}}{0,04043}
\end{aligned}
$$

Karena $n_{O_{2}}=\frac{1}{2} n_{H_{2}}$, maka didapat $\mathrm{V}_{H H O}=3714 \mathrm{n}_{H_{2}}$, atau $\mathrm{n}-H_{2}=\frac{V_{H H O}}{37141}$

Menurut persamaan Faraday $n_{H_{2}}=\frac{i t}{F Z_{H_{2}}}$, maka $\frac{V_{H H O}}{37141}=$ $\frac{i t}{f 2}, Q_{H H O}=\frac{18571}{F} i$

Dari persamaan di atas terlihat bahwa hubungan antara laju produksi HHO dengan arus listrik berupa garis lurus.

\section{SIMPULAN}

Berdasar hasil pengukuran yang telah dilakukan dapat disimpulkan beberapa hal, antara lain: pemakaian logam SS316 untuk lapisan pelat fuel cell jauh lebih baik dari aluminium karena menghasilkan resistansi lebih rendah dan konstan, laju produksi HHO pada proses elektrolisis air dipengaruhi oleh variasi lapisan pelat sejajar pada fuel celnya, nilai resistansi air yang digunakan pada pengukuran ini sebesar $\rho=4710$ $\Omega . c m$
[1] A.A. Al-Rousan, Int J HydrogEnergy, 35, 12930-5 (2010). doi:10.1016/j.ijhydene.2010.08.144.

[2] J. Wall, Effect of Hydrogen Enriched Hydrocarbon Combustion on Emissions and Performance (Panacea University, 2008).

[3] S.A. Musmar, A.A. Al-Rousan, Journal of Fuel, 90, 3066-70 (2011). doi:10.1016/j.fuel.2011.05.013.

[4] M. Daryoko, Efisiensi Elektrolisis pada Sel Elektrolisis Platina-
Platina Asam Nitrat, BATAN, Serpong, 2008.

[5] M. Vanags, J. Kleperis, G. Bajars, A. Lusis, J. Phys. Conf. Ser., 93, 132-136 (2007). doi:10.1088/1742-6596/93/1/012025.

[6] H.D. Young, Sears and Zemansky's College Physics (Young and Geller) (Online Student Access Kit. $8^{\text {th }}$ Revised edition, Addison-Wesley, San Francisco, 2006.) 